\title{
PROFIL FLAVOR ENHANCER HASIL HIDROLISIS ENZIMATIS IKAN BERNILAI EKONOMI RENDAH DALAM PENGGUNAANNYA SEBAGAI INGREDIEN PADA MAKANAN
}

Flavor Enhancer Profile Produced by Enzymatic Hydrolysis from Low Economic Value Fishes in Use asFood Ingredient

\author{
Yuli Witono $^{1) *}$, Wiwik Siti Windrati ${ }^{1)}$, Iwan Taruna ${ }^{2)}$, Ardiyan Dwi Masahid $^{1)}$, \\ Alfindya Balgies Dardiri ${ }^{1)}$ \\ ${ }^{1)}$ Program Studi Teknologi Hasil Pertanian, Fakultas Teknologi Pertanian, Universitas Jember \\ 2) Jurusan Teknik Pertanian, Universitas Jember \\ Jalan Kalimantan 37 Kampus Bumi Tegal Boto, Jember 68121 \\ *E-mail: yuliwitono.ftp@unej.ac.id
}

\begin{abstract}
A natural flavor enhancer based on local source potential is indispensable. While the potential of inferior fishes of low economic value especially in the Madura archipelago, Indonesia such as tongue ('lidah'), wedge ('baji-baji') and biblical ('bibisan') fish is very high and has not been utilized optimally. Fish raw materials can be developed as a hydrolyzate and derivatives thereof. In this case, the study aimed to find out the enzymatic hydrolysis enzymatic flavor enhancer profile of the inferior fishes with the comparison of inferior fish feedstock and additional ingredients has been performed. The study was conducted by observing descriptively the mean values of each parameter of 3 repetitions ie color, yield, moisture, ash, fat, protein, dissolved protein contentand maillard product and overall organoleptic value of flavor enhancer result of enzymatic hydrolysis process with 7 (seven) formulas of inferior fishes feedstock and additional ingredients (20:80, 40:60; 50:50; $60: 40 ; 80: 20 ; 90: 10 ; 100: 0)$ and 9 (nine) types of additives according to the treatment. The results showed that inferior fishes flavor enhancers had a diversity of their profile values due to the comparison of fish and the weight of different additives. The greater the proportion of fish raw material to the additional ingredients, the higher the level of brightness, water, fat, protein, dissolved protein content and its maillard products, but the lower the ash content and the yield. The best inferior fish flavor enhancer profile based on sensory parameters resulted from formulations with 50 grams of inferior fish and 50 grams of additional ingredients. The treatment has a flavor enhancer profile with a brightness level of 69.90; yield of 45,17 gram, water content of 1,983\%; ash content of $39.72 \%$; $2.15 \%$ fat content; protein content of 24,17\%, dissolved protein of 2,114 mg / ml; and maillard products of 0.17; as well as the overall value of organoleptic properties 2.88 (very dislike-rather like).
\end{abstract}

Keywords: biduri enzyme, flavor enhancer, formulation, and inferior fishes

\section{PENDAHULUAN}

Dunia kuliner adalah yang paling dekat dan berkepentingan dengan rasa umami. Walau secara ilmiah sumber umami baru ditemukan seabad yang lalu, namun umami sebenarnya telah diketahui jauh sebelum itu. Hanya saja, deskripsi yang digunakan berbeda-beda. Pengetahuan yang tepat dan mendalam tentang umami, sebagai elemen rasa dasar kelima, akan sangat membantu untuk memasak makanan yang lezat. Sebab, ilmu pengetahuan telah mengidentifikasikan rasa umami dapat berperan sebagai flavor enhancer dan berkontribusi terhadap savory flavor (Maga, 1998).

Potensi sumber daya ikan di Indonesia begitu besar, namun pola konsumsi makanan sebagian besar masyarakatIndonesia masih bercirikan 
pola agraris yang bertumpu pada beras dan hewan ternak darat. Di pulau Madura, ikan lidah, baji-baji dan bibisan merupakan ikan yang masih bernilai ekonomis rendah, karena jumlahnya yang berlimpah namun belum dimanfaatkan secara baik sebagai food ingredient. Sementara, hasil analisis komposisi asam amino menunjukkan bahwa ketiga ikan ini memiliki asam amino L-glutamic acid yang mengindikasikan adanya potensi sumber rasa gurih (umami) (Witono et al., 2014b). Oleh karena itu, perlu dikembangkan teknologi pengolahan dari bahan baku ikan tersebut menjadi flavor alami yang aman dan bersifat multiguna. Pengembangan pengolahan dari ikan tersebut adalah teknologi proses pembuatan garam sedap hasil hidrolisis enzimatis.

Teknologi proses pembuatan garam sedap merupakan alternatif yang diharapkan dapat mengatasi masalah kurangnya konsumsi produk-produk perikanan akibat ketidaksukaan terhadap ikan dan penyebaran produknya, yakni pengolahan ikan dalam bentuk hidrolisat protein. Hidrolisat protein ikan merupakan turunan dari protein ikan yang dapat digunakan sebagai makanan suplemen dan bahan fortifikasi berbagai makanan. Hidrolisat protein berpotensi digunakan sebagai bahan penyedap masakan atau pembangkit rasa, alternatif selain MSG (Monosodium Glutamate). Selama proses hidrolisis, substrat protein akan mengalami perubahan sedemikian rupa sehingga hidrolisat protein dapat diaplikasikan untuk tujuan tertentu (Cordle, 2001).

Flavoring agent yang sebagian besar produk-produk komersial adalah berupa senyawa sintetis atau flavor potentiator. Terdapat jenis-jenis bahan pembangkit cita rasa umum yakni asam amino $\mathrm{L}$ dan / atau garamnya (dikenal sebagai MSG), dan jenis 5'-nukleotida (dikenal sebagai 5'IMP dan 5'-GMP). Kedua bahan tersebut umum dipakai untuk melahirkan umami (rasa gurih) pada makanan (Maga, 1998). Penggunaan MSG pada makanan yang dikonsumsi sering mengganggu kesehatan karena MSG ketika dimakan akan terurai menjadi sodium dan glutamat sehingga MSG merupakan sumber natrium yang tinggi. Hasil studi Prescott and Young (2002) dalam Witono (2008) melaporkan bahwa $65 \%$ dari sampel responden mengklaim terjadi reaksi alergis pada beberapa orang akibat mengkonsumsi makanan yang telah ditambahkan MSG.

Inovasi penyedap masakan selain kaldu dan kecap, juga berupa garam sedap. Dengan asumsi kebutuhan minimal garam konsumsi sebesar $3 \mathrm{~kg} /$ tahun/kapita, maka apabila jumlah penduduk Indonesia \pm 250 juta, kebutuhan garam konsumsi sebesar 750.000 ton/tahun. Untuk itu penggunaan garam sedap sebagai penyedap masakan sangat dibutuhkan, karena bahan dasar tersedia dan pangsa pasar cukup besar. Penggunaan penyedap selama ini berupa penyedap sintetis. Penggunaan penyedap yang berasal dari garam gurih dimaksudkan untuk mengalihkan penggunaan bahan penyedap kimia ke produk garam sedap alami.

Penelitian sebelumnya dilaporkan bahwa hasil hidrolisis tiga jenis ikan inferior dari Pulau Talango, Madura secara enzimatis menggunakan protease dari tanaman biduri berpotensi sebagai flavor enhancer yang sangat kuat pada makanan (Witono et al., 2014a; Mananda et al., 2014; Witono et al., 2014b; dan Witono et al., 2014). Namun belum diketahui formulasinya terutama komposisi maupun jenis bahan tambahannya yang paling tepat sehingga dihasilkan profil flavor enhancer yang paling baik. Penelitian inibertujuan untuk menentukan perbandingan antara berat ikan terhadap berat bahan tambahan untuk menentukan profil flavor enhancer yang terbaik. Diharapkan flavor enhancer yang dihasilkan dapat digunakan sebagai penguat rasa pada makanan pengganti MSG. 


\section{METODE PENELITIAN}

\section{Bahan dan Alat}

Ikan wader laut (ikan bibisan), ikan baji-baji (ikan cucut), ikan lidah (ikan sebelah), aquades, alumunium foil, $\mathrm{NaOH}$ $1 \mathrm{~N}$, enzim biduri, enzim papain, sistein, gelatin, CMC, gula, garam, bawang merah, bawang putih bubuk, lada lubuk, asam jawa, jahe bubuk, kayu manis bubuk, dan cengkeh.

Pisau, alat pengukus, kompor gas (Quantum), blender stainless steel (GMC), pipet tetes, pipet mikro $100 \mu \mathrm{l}$ (Biohit Proline) dan $1000 \mu \mathrm{l}$ (Surepette), pipet volume $1 \mathrm{ml}$ (pyrek), pipet volume $10 \mathrm{ml}$ (pyrek), bulb pipet, waterbath (GFL 1083), neraca analitik (Ohaus), spatula besi, pemanas listrik, beaker glass, gelas ukur $1000 \mathrm{ml}$ (pyrek), oven, loyang, colour reader, termometer, $\mathrm{pH}$ meter, spektrofotometri, tanur pengabuan (Nabertherm), vortex (Thermolyne type 16700), desikator, dan kurs porselen,

\section{METODE PENELITIAN}

\section{Alat dan Bahan}

Alat yang diperlukan antara lain pisau, alat pengukus, kompor gas (Quantum), blender stainless steel (GMC), pipet tetes, pipet mikro $100 \mu \mathrm{l}$ (Biohit Proline) dan $1000 \mu \mathrm{l}$ (Surepette), pipet volume $1 \mathrm{ml}$ (pyrek), pipet volume $10 \mathrm{ml}$ (pyrek), bulb pipet, waterbath (GFL 1083), neraca analitik (Ohaus), spatula besi, pemanas listrik, beaker glass, gelas ukur $1000 \mathrm{ml}$ (pyrek), oven, loyang, colour reader, termometer, pH meter, spektrofotometri, tanur pengabuan (Nabertherm), vortex (Thermolyne type 16700), desikator, dan kurs porselen. Bahan yang digunakan antara lain ikan wader laut (ikan bibisan), ikan baji-baji (ikan cucut), ikan lidah (ikan sebelah), aquades, alumunium foil, $\mathrm{NaOH}$ $1 \mathrm{~N}$, enzim biduri, enzim papain, sistein, gelatin, CMC, gula, garam, bawang merah, bawang putih bubuk, lada lubuk, asam jawa, jahe bubuk, kayu manis bubuk, dan cengkeh.

\section{Pelaksanaan Penelitian}

Penelitian ini dilakukan dengan membandingkan antara berat ikan dan berat bahan tambahan untuk mendapatkan flavor enhancer terbaik, selanjutnya diamati sifat-sifatnya secara lengkap untuk mendapatkan gambaran tentang profil dari flavor tersebut.

\section{Rancangan Penelitian}

Penelitian dilakukan dengan mengamatisecara deskriptif nilai rerata setiap parameter dari 3 kali ulangan. Perlakuan yang terdapat pada penelitian ini adalah perbandingan bahan baku ikanterhadap bahan tambahannya. Adapun perbandingan berat ikan yang digunakan dalam hidrolisat : berat bahan tambahan sebagaimana tertera pada Tabel 1. Berat bahan tambahan yang digunakan dapat dilihat pada Tabel 2 .

Tabel 1. Perbandingan berat ikan dan berat bahan tambahan

\begin{tabular}{cc}
\hline Perlakuan & $\begin{array}{c}\text { Perbandingan berat ikan (gram) : } \\
\text { berat bahan tambahan (gram) }\end{array}$ \\
\hline A & $20: 80$ \\
B & $40: 60$ \\
C & $50: 50$ \\
D & $60: 40$ \\
E & $80: 20$ \\
F & $90: 10$ \\
G & $100: 0$ \\
\hline
\end{tabular}


Tabel 2. Berat bahan tambahan pada masingmasing perlakuan

\begin{tabular}{cccccccccc}
\hline Perla & \multicolumn{10}{c}{ kuan } & 1 & 2 & 3 & 4 & 5 & 6 & 7 & 8 & 9 \\
\hline A & 16 & 16 & 2 & 1,6 & 8 & 4 & 30 & 1,6 & 0,8 \\
B & 12 & 12 & 1,5 & 1,2 & 6 & 3 & 22,5 & 1,2 & 0,6 \\
C & 10 & 10 & 1,25 & 1 & 5 & 2,5 & 18,8 & 1 & 0,5 \\
D & 8 & 8 & 1 & 0,8 & 4 & 2 & 15 & 0,8 & 0,4 \\
E & 4 & 4 & 0,5 & 0,4 & 2 & 1 & 7,5 & 0,4 & 0,2 \\
F & 2 & 2 & 0,25 & 0,2 & 1 & 0,5 & 3,8 & 0,2 & 0,1 \\
\end{tabular}

Keterangan:

$1=$ Bawang Merah (20\%) $6=$ Jahe Bubuk (5\%)

$2=$ Bawang Putih $(20 \%) \quad 7=$ Garam $(37,5 \%)$

$3=$ Lada Bubuk $(2,5 \%) \quad 8=$ Kayu Manis Bubuk $(2 \%)$

$4=$ Gula Pasir $(2 \%) \quad 9=$ Cengkeh Bubuk $(1 \%)$

5 = Asam Jawa (10\%)

\section{Parameter Pengamatan}

Pengamatan yang dilakukan meliputi: warna (metode colour reader; Fardiaz, 1992), rendemen, kadar air (Cara Pemanasan; Sudarmadji, 1997), kadar abu (Metode Pemanasan; AOAC, 2005), kadar lemak (metode sokhlet; AOAC, 2005), kadar protein (metode Kjeldahl; Sulaeman, et al., 1995), protein terlarut (metode Lowry; Sudarmadji, 1997), Maillard (metode absorbansi; Manzocco et al., 1999), dan sifat organoleptik (Uji Kesukaan; Mabesa, 1986).

\section{Prosedur Analisis}

Warna (Tingkat Kecerahan) (Metode Colour reader; Fardiaz, 1992)

Colour reader dioperasikan dengan menekan tombol "on". Kemudian tombol target ditekan. Sebagai standart digunakan porselin yang ditempelkan pada lensa lalu tombol pengukur ditekan. Selanjutnya lensa ditempelkan pada permukaan perlakuan dengan posisi tegak lurus lalu tombol pengukur ditekan. Nilai dL yang muncul pada layar dicatat. Nilai dari $\mathrm{L}^{*}$ (Lightness) menunjukkan tingkat kecerahan dengan range $0=$ gelap sampai $100=$ terang.
Nilai $L^{*}$ dapat diperoleh dari perhitungan : $\mathrm{L}^{*}=\frac{94,35}{\text { standart } \mathrm{L}} \times \mathrm{L}$ sampel

Keterangan : standart $\mathrm{L}=62,8$

Rendemen

Rendemen adalah presentase produk yang didapatkan terhadap berat awalnya. Rendeman didapatkan dengan cara (menghitung) menimbang berat akhir bahan yang dihasilkan dari proses.

\section{Kadar Air (Cara Pemanasan; Sudarmadji, 1997)}

Menimbang botol timbang kosong yang telah dioven selama 2 jam dan diletakkan dalam eksikator, kemudian ditimbang sebagai (a) gram. Menimbang perlakuan \pm 1 gram, setelah itu menimbang berat botol dan perlakuan tersebut (b) gram. Kemudian dioven selama 24 jam, lalu didinginkan dalam eksikator dan ditimbang. Perlakuan ini diulangi sampai tercapai berat konstan (c) atau selisih penimbangan berturut-turut kurang dari 0,2 mg. Perhitungan:

$$
\text { Kadar Air }=\frac{b-c}{b-a} \times 100 \%
$$

Kadar Abu (Metode Pemanasan; AOAC, 2005)

Analisis kadar abu dilakukan dengan menggunakan metode oven. Prinsipnya adalah pembakaran atau pengabuan bahanbahan organik yang diuraikan menjadi air $\left(\mathrm{H}_{2} \mathrm{O}\right)$ dan karbondioksida $\left(\mathrm{CO}_{2}\right)$ tetapi zat anorganik tidak terbakar. Zat anorganik ini disebut abu.

Prosedur analisis kadar abu sebagai berikut: cawan yang akan digunakan dioven terlebih dahulu selama 30 menit pada suhu 100-105 ${ }^{\circ} \mathrm{C}$, kemudian didinginkan dalam desikator selama 15 menit untuk menghilangkan uap air dan ditimbang (A). Perlakuan ditimbang sebanyak 2 gram dalam cawan yang sudah dikeringkan (B), kemudian dibakar di atas nyala pembakar sampai tidak berasap dan dilanjutkan dengan pengabuan di dalam 
tanur bersuhu $550-600^{\circ} \mathrm{C}$ sampai pengabuan sempurna. Perlakuan yang sudah diabukan didinginkan dalam desikator dan ditimbang (C). Tahap pembakaran dalam tanur diulangi sampai didapat bobot yang konstan. Kadar abu dihitung dengan rumus :

$$
\text { Kadar } A b u=\frac{c-a}{b-a} \times 100 \%
$$

\section{Kadar Lemak (Metode Sokhlet; AOAC, 2005)}

Analisis kadar lemak dilakukan dengan metode sokhlet. Prinsipnya adalah lemak yang terdapat dalam perlakuan diekstrak dengan menggunakan pelarut lemak non polar. Prosedur analisis kadar lemak sebagai berikut: labu lemak yang akan digunakan dioven selama 30 menit pada suhu $100-105{ }^{\circ} \mathrm{C}$, kemudian didinginkan dalam desikator untuk menghilangkan uap air dan ditimbang (A). Perlakuan ditimbang sebanyak 2 gram (B) lalu dibungkus dengan kertas saring,kemudan dioven selama 24 jam. Setelah 24 jam dioven kemudian dimasukkan kedalam eksikator selam 30 menit, kemudian ditimbang sebagai (C) dan dimasukkan ke dalam ekstraksi sokhlet. Pelarut heksan atau pelarut lemak lain ditungkan sampai perlakuan terendam dan dilakukan refluks atau ekstraksi lemak selama 5-6 jam atau sampai pelarut lemak yang turun ke labu lemak berwarna jernih. Pelarut lemak yang telah digunakan, disuling dan ditampung setelah itu ekstrak lemak yang ada dalam labu lemak dikeringkan dalam ovan bersuhu 100-105 ${ }^{\circ} \mathrm{C}$ selama 24 jam, lalu labu lemak didinginkan dalam desikator dan ditimbang (D). Tahap pengeringan labu lemak diulangi sampai diperoleh bobot yang konstan. Kadar lemak dihitung dengan rumus:

$$
\text { Kadar Lemak }=\frac{c-d}{b-a} \times 100 \%
$$

\section{Kadar Protein (Metode Kjeldahl;} Sulaeman et al., 1995)

Analisis kadar protein dilakukan dengan metode kjeldahl. Prinsipnya adalah oksidasi bahan-bahan berkarbon dan konversi nitrogen menjadi amonia oleh asam sulfat, selanjutnya amonia bereaksi dengan kelebihan asam membentuk amonium sulfat. Amonium sulfat yang terbentuk diuraikan dan larutan dijadikan basa dengan $\mathrm{NaOH}$. Amonia yang diuapkan akan diikat dengan asam borat. Nitrogen yang terkandung dalam larutan ditentukan jumlahnya dengan titrasi menggunakan larutan baku asam.

Perlakuan ditimbang sebanyak 0,1 gram kemudian dimasukkan ke dalam labu kjeldahl. Ditambahkan 2,5-5 gram atau 0,5 - 1 selenium mix dan $\mathrm{H}_{2} \mathrm{SO}_{4}$ pekat sebanyak $7 \mathrm{ml}$. Dipanaskan mula-mula dengan api kecil, kemudian dibesarkan sampai terjadi larutan yang berwarna jernih kehijauan dengan uap $\mathrm{SO}_{2}$ hilang. Kemudian dipindahkan ke dalam labu destilasi dan ditambahkan $10 \mathrm{ml} \mathrm{NaOH}$ $10 \%$ atau lebih, kemudian disulingkan. Destilat ditampung dalam $20 \mathrm{ml}$ larutan asam borat $3 \%$. Larutan asam borat dititrasi dengan $\mathrm{HCl}$ standar dengan menggunakan metal merah sebagai indicator. Blanko diperoleh dengan cara yang sama namun tanpa menggunakan perlakuan kadar protein perlakuan dapat dihitung dengan rumus sebagai berikut:

Kadar Nitrogen:

$$
=\frac{\text { ml HCl Sampel }- \text { ml Blanko }}{\text { gram sampel x } 1000} \times \mathrm{N} \mathrm{HCl} \text { x } 100 \% \text { x 14,008 }
$$

Kadar protein $=$ kadar nitrogen $\mathrm{x} F \mathrm{FK}$ $\mathrm{FK}=6,25$

\section{Kadar Protein Terlarut (Metode Lowry; Sudarmadji, 1997)}

Menimbang perlakuan sebanyak 0,1 gram. Kemudian dilarutkan dengan aquades $10 \mathrm{ml}$. Perlakuan disentrifus selama 5 menit, diambil $0,125 \mathrm{ml}$ filtrat direaksikan dengan reagen Mix-Lowry 2,5 $\mathrm{ml}$ dan dibiarkan selama 10 menit. 
Kemudian ditambahkan follin 0,25 $\mathrm{ml}$ dan dibiarkan selama 30 menit. Ditambahkan dengan aquades sampai volume $5 \mathrm{ml}$. Kemudian ditera absorbannya dengan spektrometer pada panjang gelombang 750 nm. Data absorbansi diplotkan pada kurva standar BSA untuk dihitung kadar proteinnya.

\section{Maillard (Metode Absorbansi; Manzocco} et al., 1999)

Menimbang sebanyak 0,1 gram sampel, selanjutnya dilarutkan kedalam10 $\mathrm{ml}$ aquades kemudian divortex selama 3 menit. Setelah itu, ditera absorbansinya pada panjang gelombang $420 \mathrm{~nm}$.

\section{Uji Organoleptik (Uji Kesukaan; Mabesa,} 1986)

Uji organoleptik yang digunakan dalam penelitian ini adalah menggunakan uji kesukaan yang meliputi aroma, warna, rasa dan kesukaan keseluruhan dengan menggunakan minimal 20 orang panelis. Cara pengujian ini dilakukan secara acak dengan menggunakan perlakuan yang telah terlebih dahulu diberi kode. Konsentrasi flavor enhancer yang ditambahkan 3 gram/100 gram bahan. Panelis diminta menentukan tingkat kesukaan mereka terhadap hidrolisat ikan inferior. Untuk uji kesukaan rasa diaplikasikan pada sup. Untuk uji kesukaan aroma, setiap panelis cukup dengan mencium aroma garam gurih menggunakan indra pencium. Untuk uji kesukaan warna, setiap panelis cukup melihat kenampakan warna garam gurih dengan indra penglihat. Jenjang skala uji kesukaan terhadap rasa, aroma, warna dan keseluruhan dari masing-masing perlakuan adalah sebagai berikut :

Skala Hedonik

Skala Numerik

1. Sangat tidak suka 1

2. Tidak suka 2

3. Agak suka 3

4. Suka 4

5. Sangat Suka 5

\section{HASIL DAN PEMBAHASAN}

\section{Warna (Tingkat Kecerahan)}

Warna yang dihasilkan oleh flavor enhancer diukur berdasarkan tingkat kecerahan. Nilai rata-rata kecerahan sebesar 46,01 sampai 49,77. Adapun histogram nilai kecerahan flavor enhacer dapatdilihat pada Gambar 1.

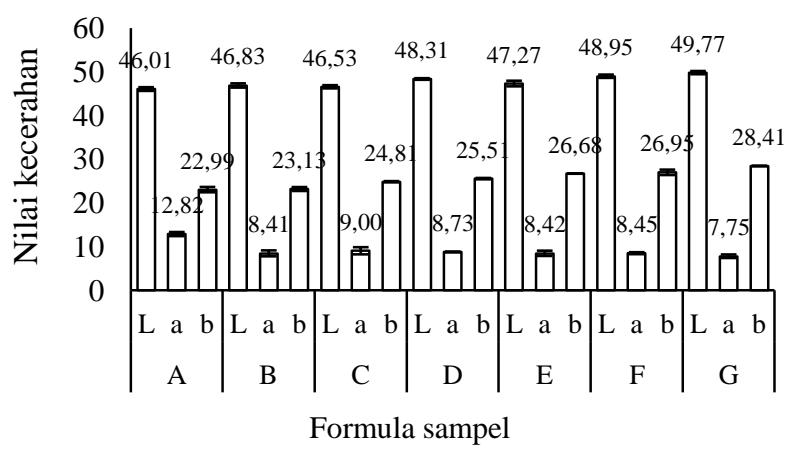

Gambar 1. Nilai kecerahan flavor enhancer

Gambar 1 menunjukkan bahwa semakin besar proporsi bahan baku ikan inferior terhadap bahan tambahan, nilai kecerahan yang dihasilkan cenderung semakin tinggi. Hal ini berhubungan dengan warna dari bahan tambahan yang digunakan cenderung berwarna kecoklatan, sehingga semakin tinggi proporsi bahan baku ikan inferior atau semakin rendah bahan tambahannya, produk yang dihasilkan semakin cerah. Walau menurut hasil penelitian sebelumnya (Witono et al., 2014 dan Mananda et al., 2014) dilaporkan bahwa hidrolisat yang memiliki nilai rasa gurih ('umami') yang tinggi cenderung berwarna kecoklatan akibat reaksi maillard, namun kontribusi warna kecoklatan dari hidrolisat tidak sebanding dengan kontribusi warna kecoklatan dari bahan tambahannya. Bahan tambahan yang sebagian besar berupa rempah secara natif berwarna kecoklatan / gelap. 


\section{Rendemen}

Berdasarkan analisa rendemen, diperoleh hasil sebagaimana dilihat pada Gambar 2.

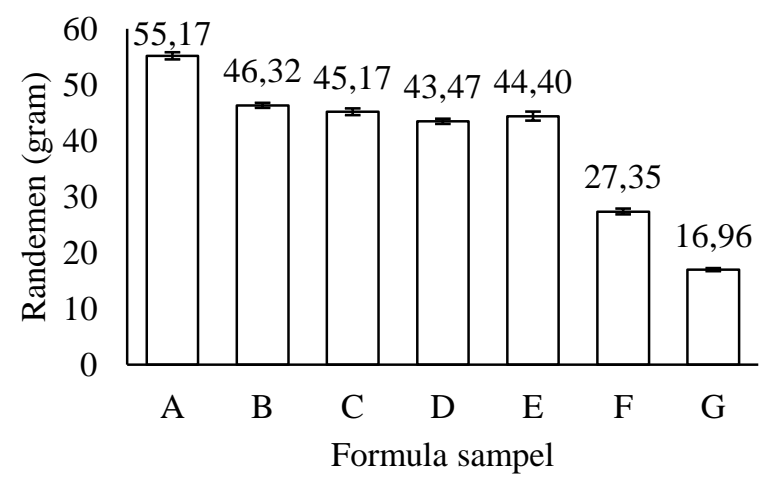

Gambar 2. Rendemen flavor enhancer

Gambar 2 diketahui bahwa semakin besar proporsi bahan bakuikan inferior terhadap bahan tambahan cenderung menghasilkan rendemen produk akhir flavor enhancer yang semakin menurun. Hal ini diduga karena berkaitan dengan berkurangnya sebagian komponen volatile dan komponen lain seperti air yang terkandung dalam bahan baku hidrolisat basah mengalami penguapan selama proses pengeringan. Peningkatan komponen hasil hidrolisis seperti padatan terlarut, asam-asam amino, dan komponen lainnyayang seiring dengan penurunan kadar air juga menjadi penyebab menurunnya rendemen selama proses pengeringan. Terlebih pada sampel $G$ (100\% hidrolisat ikan inferior) berat rendemen yang dihasilkan paling kecil karena tidak ada campuran bahan tambahan pada formulasi sampel yang berkontribusi terhadap rendemen produk akhir.

\section{Kadar Air}

Berdasarkan hasil analisa kadar air didapatkan bahwa nilai rerata dari 3 kali ulangan pada semua formula sampel sebagaimana tertera pada Gambar 3.

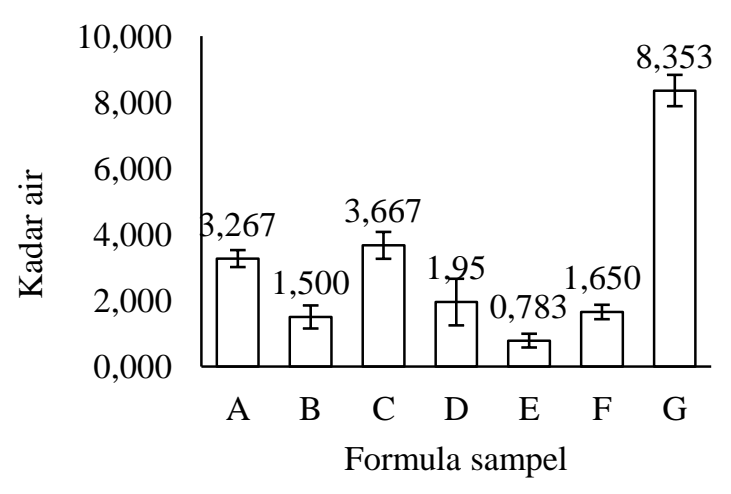

Gambar 3. Kadar air flavor enhancer

Gambar 3 menunjukkan bahwa kadar air flavor enhancer sangat variatif yang tidak seiring secara konsisten dengan peningkatan maupun penurunan proporsi bahan baku hidrolisat protein ikan inferior terhadap bahan tambahannya. Kadar air pada formula sampel A sebesar 3,27\% kemudian mengalami penurunan pada sampel B menjadi 1,50\%. Kadar air pada sampel $\mathrm{C}$ mengalami kenaikan menjadi $3.67 \%$. Pada formula sampel D menurun menjadi $1,95 \%$, demikian juga pada formula sampel $\mathrm{E}$ semakin menurun menjadi $0,783 \%$, kemudian meningkat menjadi $1,65 \%$ pada sampel $\mathrm{F}$ dan terus meningkat secara tajam menjadi $8,353 \%$ pada sampel G. Bila dicermati dari 3 formula tersebut mengindikasikan ada kecenderungan terjadi peningkatan seiring dengan peningkatan proporsi bahan baku hidrolisat terhadap bahan tambahannya terutama pada formula sampel A, C dan G (tanpa bahan tambahan atau 100\% hidrolisat protein ikan inferior). Hal ini tentu terkait dengan kadar air yang terkandung dalam bahan baku ikan inferior (sebagaimana indikasi pada Gambar 2). Semakin tinggi hidrolisat protein dari bahan baku ikan inferior yang ditambahkan berarti semakin tinggi kadar protein dan kadar protein terlarutnya maka tingkat hidrasi meningkat yang berakibat kadar air terhitung pada produk akhir flavor cenderung lebih tinggi (Prasulistyowati, 2011). Bahan tambahan yang sebagian berupa rempah kering tentu 
tidak berkontribusi signifikan terhadap kenaikan kadar air produk akhir flavor enhancer.

\section{Kadar Abu}

Hasil analisa kadar abu diperoleh nilai rerata dari 3 kali ulangan pada semua formula sampel sebagaimana tertera pada Gambar 4.

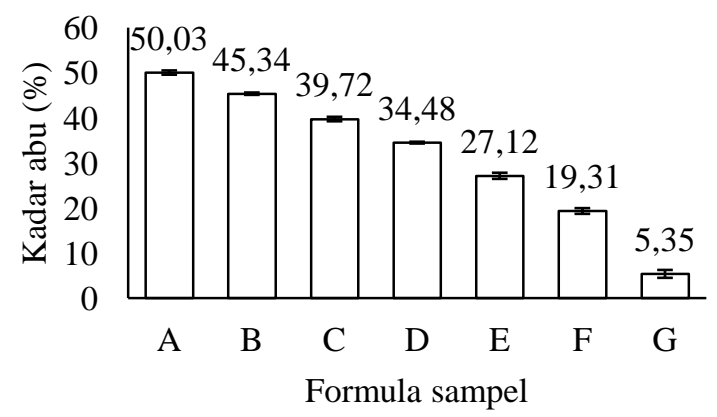

Gambar 4. Kadar abu flavor enhancer

Kadar abu dapat menunjukkan total mineral dalam suatu bahan pangan. Menurut Winarno (1995), sebagian besar bahan makanan, yaitu sekitar $96 \%$ terdiri dari bahan organik dan air. Sisanya terdiri dari unsur-unsur mineral. Unsur mineral juga dikenal sebagai zat anorganik atau kadar abu. Kadar abu yang diperoleh pada produk flavor enhancer ikan inferior cenderung menurun, hal ini karena kontribusi mineral dari hidrolisat protein yang sebagian besar terususun atas senyawa organik dan protein kontribusinya terhadap mineral dan kadar abu jauh lebih kecil dibanding bahan tambahan yang sebagian berasal dari garam dan rempahrempah kering. Witono et al. (2013) juga melaporkan bahwa garam sedap hasil pencampuran hidrolisat dari ikan kuwe juga menunjukkan kadar abu yang tinggi setelah proses pengeringan.

Gambar 4 juga menunjukkan bahwa formula sampel A memiliki kadar abu sebesar $50.03 \%$. Hal ini dipengaruhi oleh banyaknya kadungan garam (mineral) dan bahan tambahan lain yang mengandung mineral. Semakin berkurang ingredien yang ditambahkan termasuk garam di dalamnya atau semakin kecil proporsi bahan baku ikan inferior mengindikasikan semakin tinggi kadar abunya. Fenomena sebaliknya terjadi, hingga pada sampel $\mathrm{F}$ yang ditambahkan ingredian dan garam yang paling kecil dan sampel $G$ tanpa ingredient dan garam. Sesuai dengan pernyataan Sudarmadji et al. (1997), bahwa kadar abu tergantung pada jenis bahan, cara pengabuan, waktu dan suhu yang digunakan saat pengeringan.

\section{Kadar Lemak}

Hasil analisa kadar lemak diperoleh nilai rerata dari 3 kali ulangan pada semua formula sampel. Hasil sebagaimana tertera pada Gambar 5.

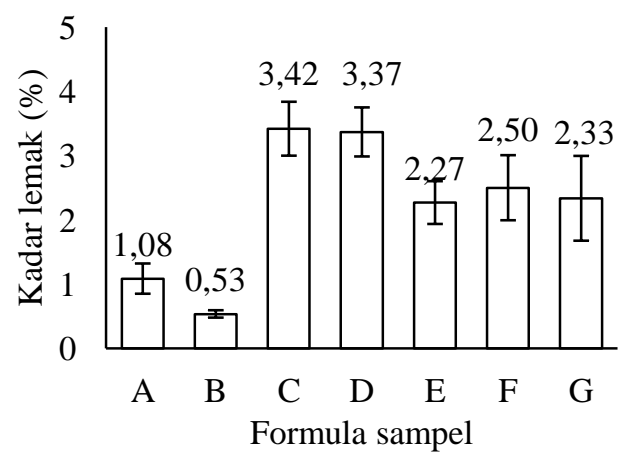

Gambar 5. Kadar lemak flavor enhancer

Berdasarkan Gambar 5 tersebut diatas menunjukkan bahwa kadar lemak flavor enhancer cenderung menurun. Kandungan lemak pada flavor enhancer memang fluktuatif namun cenderung mngalami penurunan setelah formula sampel D hingga sampel G. Penurunan kadar lemak pada flavor enhancer dipengaruhi oleh peningkatan kadar air pada flavor enhancer. Sejalan dengan penelitian Zuhra et al. (2012), menyatakan bahwa meningkatnya kadar lemak dengan suhu pengeringan yang tinggi dapat disebabkan oleh penurunan kadar air sehingga persentase kadar lemak dalam sampel meningkat. Kadar air dan kadar lemak memiliki hubungan yang 
berbanding terbalik, jika kadar air semakin tinggi maka kadar lemak yang dihasilkan akan semakin menurun.

Hal ini karena semakin lama waktu dan semakin tinggi suhu yang digunakan pada proses pengeringan akan semakin menyebabkan peningkatan kadar lemak dan berbanding terbalik dengan nilai kadar air yang semakin menunjukkan penurunan seiring dengan semakin tinggi suhu dan waktu yang digunakan selama proses pengeringan. Sejalan dengan penelitian Yuniarti (2007), yang menyatakan bahwa dengan lamanya waktu dan tinggi suhu yang digunakan pada proses pengeringan akan menyebabkan kandungan lemak yang ada pada bahan juga semakin meningkat dan kandungan air yang semakin menurun.

\section{Kadar Protein}

Hasil analis akadar protein diperoleh nilai rerata dari 3 kali ulangan pada semua formula sampel. Hasil sebagaimana tertera pada Gambar 6.

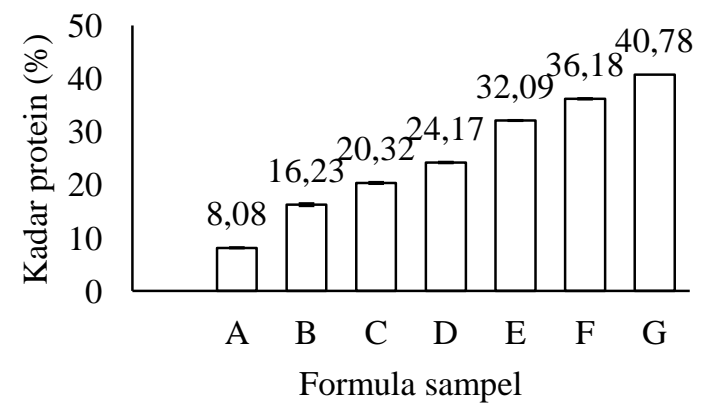

Gambar 6. Kadar protein flavor enhancer

Gambar 6 diketahui bahwa kadar protein pada flavor enhancer ikan inferior mengalami kenaikan seiring dengan kenaikan proporsi bahan baku hidrolisat protein ikan inferior. Kenaikan protein pada sampel dapat terjadi karena adanya keterkaitan erat dengan penambahan bahan baku hidrolisat protein ikan inferior pada formula sampel. Sampel A memiliki jumlah ikan inferior yang paling sedikit ditambahkan, sedangkan pada sampel $G$ memiliki jumlah ikan inferior yang paling banyak digunakan untuk membuat flavor enhancer. Kadar protein juga dipengaruhi oleh karakteristik bahan tambahannya yang sebagian besar bahan non protein, sehingga semakin sedikit bahan tambahannya kadar proteinnya juga semakin kecil. Sebagaimana pada formula sampel $G$ yang tidak menggunakan bahan tambahan sama sekali, sementara formula sampel tersebut $100 \%$ berasal dari bahan ikan inferior.

\section{Kadar Protein Terlarut}

Hasil analisa kadar protein terlarut diperoleh nilai rerata dari 3 kali ulangan pada semua formula sampel sebagaimana tertera pada Gambar 7.

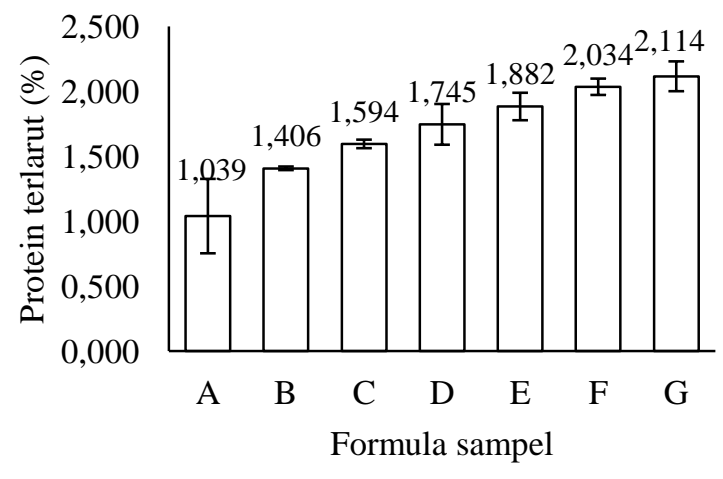

Gambar 7. Kadar protein terlarut flavor enhancer

Gambar 7 menunjukkan bahwa dengan meningkatnya proporsi bahan baku hidrolisat protein ikan inferior mengindikasikan peningkatan kadar protein terlarutnya. Hal ini karena seiring dengan peningkatan kadar protein total dari flavor enhancer yang dihasilkan juga meningkat. Semakin tinggi kadar protein total dalam bahan selama proses tersebut juga akan menghasilkan protein terlarut yang semakin tinggi akibat proses enzimatis dari protease yang digunakan.

\section{Produk Maillard}

Nilai produk maillard flavor enhancer ikan inferior pada berbagai sampel berkisar antara 0,120-0,356. Produk maillard dinyatakan dalam 
absorbansi unit. Semakin tinggi absorbansi maka produk maillard semakin meninggkat. Hal ini sebagimana ditunjukkan oleh Gambar 8.

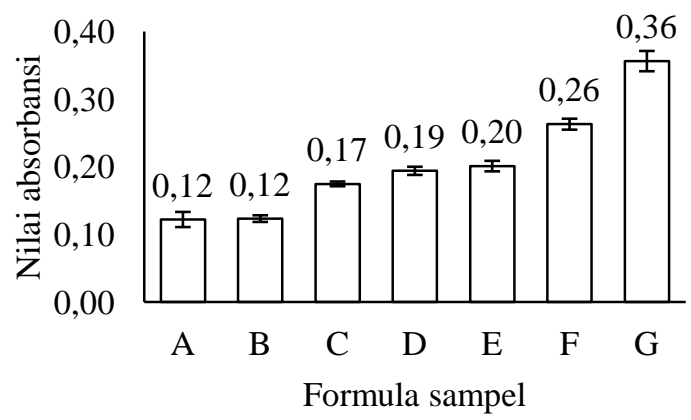

Gambar 8. Produk reaksi maillard flavor enhancer

Gambar 8 menunjukkan bahwa semakin besar proporsi bahan baku hidrolisat protein ikan inferior terhadap bahan tambahan maka nilai produk maillard hidrolisat protein ikan inferior yang dihasilkan cenderung semakin tinggi. Hal ini terjadi karena semakin banyak protein dan protein terlarut yang berkontribusi terhadap semakin banyaknya gugus amina primer yang beraksi dengan gugus karboksil dari gula sehingga produk reaksi maillard yang dihasilkan juga semakin banyak. Menurut Heath and Reineccius (1986), reaksi maillard merupakan reaksi antara gugus karbonil dan gugus amina primer. Dengan semakin banyaknya hidrolisat protein yang ditambahkan, maka semakin tinggi pula nilai produk maillard yang dihasilkan.

\section{Sifat Organoleptik}

Tingkat kesukaan warna

Nilai kesukaan warna flavor enhancer dari hidrolisat protein ikan inferior berkisar antara 2,52-3,04 (tidak suka-agak suka). Diagram tingkat kesukaan kecerahan warna dapat dilihat pada Gambar 9, yang menunjukkan bahwa sampel $\mathrm{E}$ memiliki tingkat kesukaan warna tertinggi yaitu 3,04. Sampel E terdiri dari 80 gram ikan inferior dan 20 gram bahan tambahan, para penelis memiliki kesukaan warna yang cederung terang. Pada uji panelis yang telah dilakukan, sampel A memiliki nilai tingkat kesukaan paling rendah yaitu 2,52. Warna yang dihasilkan oleh sampel A berwarna lebih gelap diantara sampel yang lain.

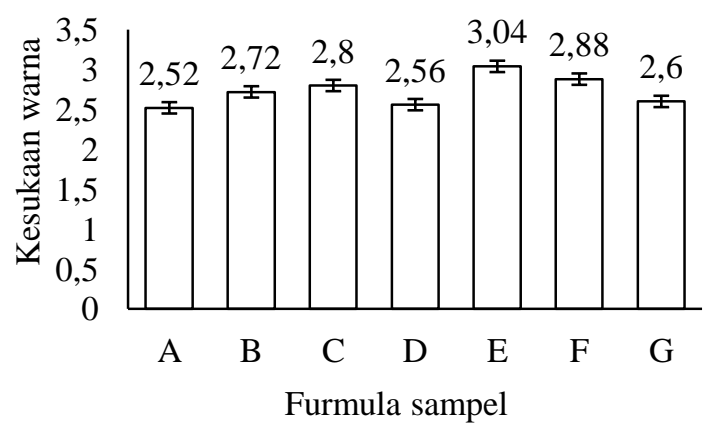

Gambar 9. Nilai kesukaan warna flavor enhancer

Tingkat kesukaan warna pada flavor enhancer ini berhubungan dengan produk maillard yang merupakan reaksi yang membentuk warna coklat. Menurut Winarno (1983) produk maillard yang dihasilkan akan berkondensasi dengan produk reaksi lain untuk membentuk melanoidin dan mempengaruhi kecerahan garam gurih, yakni semakin tinggi produk maillard yang dihasilkan akan membentuk senyawa melanoidin yang tinggi pula, sehingga tingkat kecerahan akan semakin menurun. Terbentuknya warna gelap pada flavor enhancer juga dipengaruhi oleh banyaknya bahan tambahan yang digunakan dalam pembuatan flavour enhancer.

\section{Tingkat kesukaan aroma}

Nilai kesukaan aroma flavor enhancer dari hidrolisat protein ikan inferior berkisar antara 1,84-2,76 (sangat tidak suka-agak suka). Diagram tingkat kesukaan kecerahan aroma dapat dilihat pada Gambar 10. 


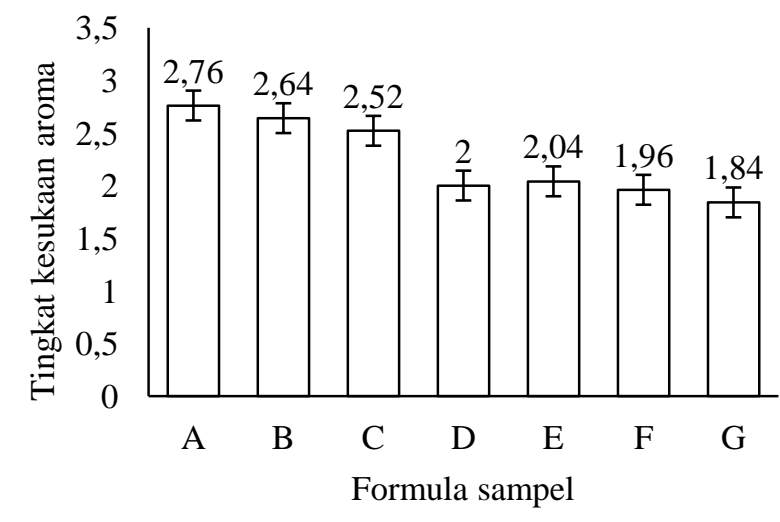

Gambar 10. Tingkat kesukaan aroma flavor enhancer

Gambar 10 menunjukkan bahwa nilai tingkat kesukaan aroma pada flavor enhancer yang semakin menurun. Sampel yang lebih disukai oleh para panelis adalah pada sampel A. Sampel A terdiri dari 20 gram ikan inferior dan 80 gram bahan tambahan. Pengaruh dari rempah yang ditambahkan dapat menimbulkan aroma yang khas dari flavor enhancer, pada seluruh sampel aroma yang paling muncul adalah pada sampel A, sedangkan pada sampel $\mathrm{G}$ memiliki tingkat kesukaan yang paling rendah karena pada sampel $G$ tidak diberikan bahan tambahan seperti sampel yang lain. Karena sampel G yang 100 gram bahannya hanya menggunakan ikan inferior, maka aroma yang muncul hanya aroma ikan dan tidak menghasilkansensasi aroma rempah yang dapat ditimbulkan oleh sampel lain.

\section{Tingkat kesukaan rasa}

Nilai kesukaan rasa flavor enhancer dari hidrolisat protein ikan inferior berkisar antara 1,64-2,76 (sangat tidak suka-agak suka). Diagram tingkat kesukaan rasa dapat dilihat pada Gambar 11.

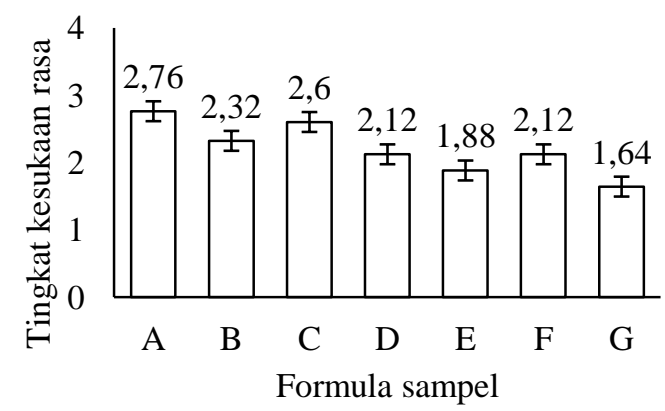

Gambar 11. Tingkat kesukaan rasa flavor enhancer

Gambar 11 dapat dilihat bahwa panelis lebih menyukai rasa flavor enhancer yang memiliki bahan tambahan lebih banyak. Pada sampel A yang terdiri dari 20 gram ikan dan 80 gram bahan tambahan, memiliki nilai kesukaan yang lebih tinggi. Panelis lebih menyukai bumbu yang telah ditambahkan pada flavor enhancer, dengan perbandingan 20 gram ikan inferior dan 80 gram bahan tambahan. Selain sampel A, sampel yang juga disukai oleh para panelis adalah sampel C, dengan berat ikan inferior 50 gram dan berat bahan tambahan sebanyak 50 gram. Maka flavor enhancer yang dihasilkan lebih masih terasa sensasi rempanya dibandingkan rasa hidrolisat ikan inferiornya saja.

\section{Tingkat kesukaan keseluruhan}

Nilai kesukaan keseluruhan flavor enhancer dari hidrolisat protein ikan inferior berkisar antara 1,96-2,88 (sangat tidak suka-agak suka). Diagram tingkat kesukaan tingkat kesukaan keseluruhan dapat dilihat pada Gambar 12. 


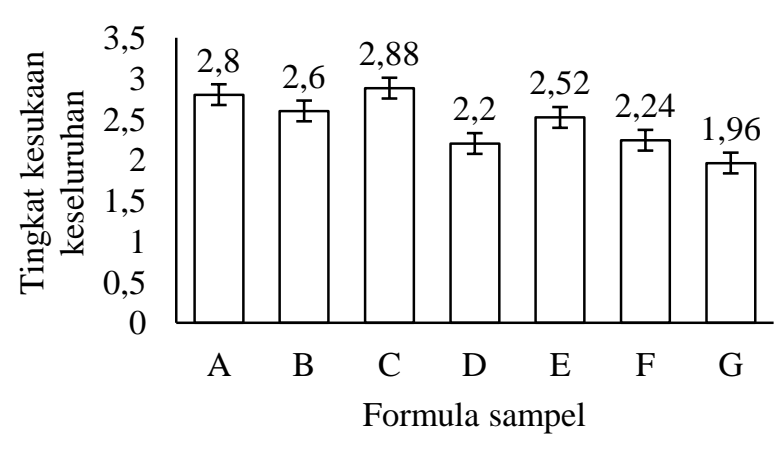

Gambar 12. Tingkat kesukaan keseluruhan flavor enhancer

Gambar 12 menunjukkan bahwa tingkat kesukaan keseluruhan pada flavor enhancer berkisar antara nilai 1,96 sampai 2,88 . Nilai tingkat kesukaan yang tertinggi adalah pada sampel C. Pada sampel C berat ikan inferior yang digunakan adalah 50 gram dan 50 gram bahan tambahan. Panelis lebih menyukai sampel $\mathrm{C}$ dikarekan formulanya balance yakni masih terasa flavor ikan dengan sensai rempah yang masih kuat sehingga keseluruhan penilaian membuktikan bahwa sampel $\mathrm{C}$ lebih baik diantara sampel yang lain. Dari parameter warna sampel C memiliki warna yang lebih disukai oleh panelis, karena warna yang dihasilkan lebih berwarna coklat terang. Sampel C juga memiliki aroma yang lebih disukai karena rempah yag digunakan masih terasa sehingga sensasi aroma ikan dan rempah keduanya masih dikenali dan dirasakan dengan baik dan kuat.

\section{KESIMPULAN}

Flavor enhancer dari hidrolisat protein ikan inferior memiliki keragaman nilai profilnya akibat perlakuan perbandingan ikan dan berat bahan tambahan yang berbeda. Semakin besar proporsi bahan baku ikan terhadap bahan tambahan diperoleh flavor yang semakin tinggi tingkat kecerahan, kadar air, lemak, protein, protein terlarut dan produk reaksi maillard-nya, akan tetapi semakin rendah kadar abu dan rendemennya. Profil flavor enhancer ikan inferior terbaik berdasar parameter sensoris dihasilkan dari formulasi dengan perbandingan 50 gram ikan inferior dan 50 gram bahan tambahan. Perlakuan tersebut memiliki profil flavor enhancer dengan tingkat kecerahan 69,90; rendemen 45,17 gram, kadar air 1,983\%; kadar abu 39,72\%; kadar lemak 2,15\%; kadar protein $24,17 \%$, protein terlarut $15,58 \mathrm{mg} / \mathrm{ml}$; dan produk maillard 0,17 ; serta nilai keseluruhan sifat organoleptik 2,88 (sangat tidak suka-agak suka).

\section{UCAPAN TERIMA KASIH}

Disampaikan terima kasih kepada DRPM Kemenristek dan Dikti atas dukungan pendanaannya dalam penyelesaian penelitian ini.

\section{DAFTAR PUSTAKA}

AOAC. 2005. Official Methods of Analysis of the Association of Analytical Chemist. Association of Official Chemist. Washington, D.C.

Cordle, C.T. 2001. Control of food allergies using protein hydrolysates. Food Technol., 48 (10): 72-76.

Fardiaz, S. 1992. Mikrobiologi Pangan I. PT. Gramedia Pustaka Utama. Jakarta.

Heath, H.B. and Reineccius, G., 1986. Flavour Chemistry and Technology. Van Nostrand Reinhold, New York.

Mabesa, I. B. 1986. Sensory Evaluation of Foods Principles and Methods. College of Agriculture. UPLB. Laguna.

Maga, J. A., 1998, Umami Flavor of Meat, In Shahidi, F. ed. "Flavor of Meat, Meat Products and Seafoods", Blackie Academic \& Professional, London, pp: 197-215.

Mananda, A.B., Witono, Y., Taruna, I., and Won, K.W. 2014. Physicochemical and functional properties of mixed fishes hydrolysates obtained enzymaticly from Apogon albimaculosus, Platycephalidae cymbacephalus and Cynoglossus lingua. International Symposium and Annual Meeting of KSABC, Korea, 19-21 June 2015. 
Manzocco, L, Nicoli, M.C., Anese, M., Pitotti, A. and Maltini, E. 1999. Polyphenoloxidase and Peroxidase Activity in Partially Fronzen Systems with Different Physical Properties. Food Res. Int.

Prasulistyowati, T. E. 2011. "Modifikasi Hidrolisis Enzimatis Koro Kratok Menggunakan Campuran Enzim Protease Biduri dan Papain untuk Memproduksi Flavor Enhancer". Skripsi. Fakultas Teknologi Pertanian, Universitas Jember, Jember.

Sudarmadji, S., B. Haryono and Suhardi. 1997. Procedures for the Analysis of Food and Agriculture. Liberty, Yogyakarta.

Sulaeman, Faisal, A.A., Rimbawan dan Anna, M.S. 1995. Metode Analisis Komponen Zat Gizi Makanan. Jurusan Gizi Masyarakat dan Sumber Daya Keluarga, Fakultas Pertanian IPB. Bogor.

Winarno, F.G. 1983. Enzim Pangan. PT. Gramedia Pustaka Utama, Jakarta.

Winarno, F.G.,1995. Kimia Pangan dan Gizi. PT. Gramedia Pustaka Utama, Jakarta.

Witono, Y. 2008. "Eksplorasi Enzim Protease dari Tanaman Biduri (Calotropis gigantea) dan Pemanfaatannya pada Pengolahan Pangan". Disertasi. Program Doktor Ilmu Pertanian. Universitas Brawijaya, Malang.

Witono, Y., Mananda, A.B., Windrati, W.S.and Won, K.W. 2014a. Savory Salt Production and Characterization from Mixed Fishes Protein Hydrolysates. International Symposium and Annual Meeting of KSABC, Korea, 19-21 June 2014.

Witono, Y., Windrati, W.S., dan Zamroni, I. 2013. Telaah teknologi pembuatan garam sedap hasil hidrolisis dari ikan kuwe berbasis teknik hidrolisis enzimatis menggunakan protease biduri. Prosiding Seminar Nasional Perhimpunan Ahli Teknologi Pangan Indonesia, Jember, 28-31 Agustus 2013.
Witono, Y., Taruna, I., and Windrati. W.S. 2014b. Amino acids profiles and chemical properties of four inferior sea fishes in Madura, Indonesia. International Journal of ChemTech Research, 6 (1): 311-315.

Witono, Y., Taruna, I., Windrati. W.S., dan Ratna, A. 2014. Hidrolisis ikan bernilai ekonomi rendah secara enzimatis menggunakan protease biduri. Jurnal Teknologi dan Industri Pangan, 25 (2): 140-145.

Yuniarti, N., Syamssuwida, D. dan Aminah, A. 2007. Pengaruh penurunan kadar air terhadap perubahan fisiologi dan kandungan biokimia benih eboni (Diospyros celebica Bahk.). Jurnal Penelitian Hutan Tanaman, 5 (3): 191198.

Zuhra, S. dan C. Erlina. 2012. Pengaruh kondisi operasi alat pengering semprot terhadap kualitas susu bubuk jagung. Jurnal Rekayasa Kimia dan Lingkungan, 9 (1): 36-44. 